\title{
COVID-19 PANDEMIC AND AN URGENT NEED OF ONLINE LEARNING APPROACHES IN NEPAL AND OTHER DEVELOPING NATIONS
}

Ansari $M$

\begin{abstract}
Affiliation
1. Department of Clinical Pharmacy, College of Pharmacy, University of Hail, Saudi Arabia.
\end{abstract}

\section{ARTICLE INFO}

Received : 26 February, 2020

Accepted : 06 April, 2020

Published : 30 June, 2020

(c) Authors retain copyright and grant the journal right of first publication with the work simultaneously licensed under Creative Commons Attribution License CC - BY 4.0 that allows others to share the work with an acknowledgment of the work's authorship and initial publication in this journal.

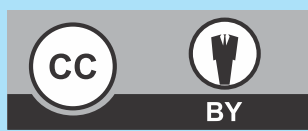

VP 3

DOI: https://doi.org/10.3126/bjhs.v5i1.29652

\section{* Corresponding Author}

Dr. Mukhtar Ansari

Department of Clinical Pharmacy

College of Pharmacy

University of Hail, Saudi Arabia

Email: mukhtaransari@hotmail.com

ORCID ID: https://orcid.org/0000-0002-5247-6356

\section{ABSTRACT}

COVID-19 outbreak is pandemic worldwide with increasing total reported cases, new cases and total deaths. This devastating situation has affected every corner of human lives including academic sector globally. Although there are various measures to prevent spread of COVID-19 infection, online education could be the most suitable option concerning academic institutions to curb its spread, and developing nations including Nepal are in urgent need to implement it.

\section{KEYWORDS}

COVID-19, developing nations, Nepal, online learning, pandemic.

\section{Citation}

Ansari M. Covid-19 Pandemic and an Urgent Need of Online Learning Approaches in Nepal and other Developing Nations. BJHS 2020;5(1)11:877-878 
It is quite distressing that COVID-19 outbreak, initially started from Wuhan, a city in the Hubei Province of China, has become pandemic globally. COVID-19 seems to reach a new and catastrophic breakthrough every day. According to the World Health Organization (WHO) COVID-19 situation report-101 (30 APRRIL 2020), nearly 3.1 million confirmed cases and more than 217 thousands deaths have been reported globally till date and the trends are rampant. ${ }^{1}$ Till few weeks ago, the confirmed cases of COVID-19 infection were comparatively low in South East Asia Region including Nepal and India, but the recent trend shows a surge of the infection in this region too. ${ }^{1}$ This devastating situation has affected every corner of human lives including academic sector globally. Governments all around the world including Nepal have taken all possible necessary precautions; closed educational institutions and even locked down in an attempt to control the global pandemic.

According to the United Nations Educational, Scientific and Cultural Organization (UNESCO) monitoring, more than 100 countries have implemented nationwide closures, disrupting education over half of world's students. ${ }^{2,3}$ It is evident that transmission of virus may take place though airborne (aerosol), droplet spray and direct contact, and indirect (fomite); and the schools are one of the most vulnerable places for such transmission. ${ }^{4}$ In this situation, it is obvious for the Government of Nepal to extend lockdown period, and it is still uncertain that how long does it persist. However, we still have option in context to academic activities to continue with and prevent the spread of COVID-
19 infection through use of electronic learning or virtual classes which most of the developed countries including Saudi Arabia have been practicing in this emergency situation. This start up would be the most suitable alternative to prevent the spread of COVID-19 infection without much affecting the academic activities. Schools and universities in industrialized nations are moving to online instruction to curb the spread of the coronavirus. However, there are challenges with electronic learnings particularly with developing countries, such as infrastructure, training of educators to improve IT competencies, need of multi disciplinary team support, and issues related to equity as some students don't have access to computers, internet access, or a safe, supportive learning environment outside of school. ${ }^{5}$ Despite these challenges, I still believe that switching to online classes would be a better choice.

There are variety of digital or online software for live sessions and some of which includes Blackboard collaborate, Zoom, Canvas, Panopto, WizIQ, Electa live, Eliademy, BrainCert, ezTalks Webinar, Edvance 360 Learning Management Software and eTrainCenter Software. Currently, we have been successfully using Blackboard Collaborate to deliver live lectures to the students, conducting online quizzes and assignments in this emergency situation at the University of Hail, Saudi Arabia.

Thus, I would like to draw the attention of the Ministry of Education, Government of Nepal to coordinate with academic institutions and encourage them to commence with online classes.

\section{REFERENCES}

1. WHO. Coronavirus disease 2019 (COVID-19) Situation Report - 101 Available from: https://www.who.int/docs/default-source/ coronaviruse/ situation-reports/20200430-sitrep-101-covid19.pdf?sfvrsn=2ba4e093_2. [Last accessed 2020 APR 30].

2. UNESCO. COVID-19 Educational Disruption and Response. Available from: https://en.unesco.org/themes/education-emergencies/ coronavirus-school-closures. [Last accessed 2020 Mar 21].

3. Pradhan TR. Oli announces suspension of all flights, all long-haul transport and all non-essential services. The Kathmandu Post. Available from: https://kathmandupost.com/national/2020/03/20/ oli-announces-suspension-of-all-flights-all-long-haul-transportand-all-non-essential-services. [Last accessed 2020 Mar 21].
4. Moriyama M, Hugentobler WJ, Iwasaki A. Seasonality of respiratory viral infections. Annu Rev Virol, 7:2.1-2.19, 2020. https://doi.org/ 10.1146/ annurev-virology-012420-022445

5. Janse van Rensburg, ES. Effective online teaching and learning practices for undergraduate health sciences students: An integrative review. International Journal of Africa Nursing Sciences, 9: 73-80, 2018. 